\title{
Memory And the City IN ANCIENT ISRAEL
}





\section{Memory AND the City IN ANCIENT ISRAEL}

EDITED By

Diana V. Edelman and Ehud Ben Zvi

Winona Lake, Indiana

EISENBraUnS

2014 
(C) Copyright 2014 Eisenbrauns Inc.

All rights reserved.

Printed in the United States of America.

www.eisenbrauns.com

\section{Library of Congress Cataloging-in-Publication Data}

Memory and the city in ancient Israel / edited by Diana V. Edelman and Ehud Ben Zvi.

pages $\mathrm{cm}$

Includes bibliographical references and index.

ISBN 978-1-57506-315-7 (paperback : alkaline paper)

1. Cities and towns, Ancient-Palestine. 2. Palestine-

Civilization-To 1500 3. Civilization, Ancient-Palestine. 4. City planning-Palestine-History-To 1500. 5. City planning-Social aspects-Palestine-History-To 1500. 6. Public spaces-

Palestine-History-To 1500. I. Edelman, Diana Vikander, 1954-

editor. II. Ben Zvi, Ehud, 1951- editor.

HT147.P27M46 2014

$307.76095694-\mathrm{dc} 23$

2014036051

The paper used in this publication meets the minimum requirements of the American National Standard for Information Sciences-Permanence of Paper for Printed Library Materials, ANSI Z39.48-1984. ${ }^{\mathrm{TM}} \otimes$ 